\title{
Long-term differentiating primary human airway epithelial cell cultures: how far are we?
}

\author{
Zuzanna Bukowy-Bieryłł *
}

\begin{abstract}
Background: Human airway epithelial (HAE) cellular models are widely used in applicative studies of the airway physiology and disease. In vitro expanded and differentiated primary HAE cells collected from patients seem to be an accurate model of human airway, offering a quicker and cheaper alternative to the induced pluripotent stem cell (iPSCs) models. However, the biggest drawback of primary HAE models is their limited proliferative lifespan in culture. Much work has been devoted to understand the factors, which govern the HAE cell proliferation and differentiation, both in vivo and in vitro. Here, I have summarized recent achievements in primary HAE culture, with the special emphasis on the models of conditionally reprogrammed cells (CRC), which allow longer in vitro proliferation and differentiation of HAE cells. The review compares the CRC HAE technique variants (feeder culture or HAE mono-culture), based on recently published studies exploiting this model. The advantages and limitations of each CRC HAE model variant are summarized, along with the description of other factors affecting the CRC HAE culture success (tissue type, sampling method, sample quality).
\end{abstract}

Conclusions: CRC HAE cultures are a useful technique in respiratory research, which in many cases exceeds the iPSCs and organoid culture methods. Until the current limitations of the IPSCs and organoid culture methods will be alleviated, the primary CRC HAE cultures might be a useful model in respiratory research.

Plain English summary: Airway epithelium (AE) is a type of tissue, which lines the whole length of human airways, from the nose to the bronchi. Improper functioning of AE causes several human airway disorders, such as asthma, chronic obstructive pulmonary disease (COPD) or cystic fibrosis (CF). Much work has been devoted to finding the best scientific model of human $A E$, in order to learn about its functioning in health and disease. Among the popular AE models are the primary in vitro cultured AE cells collected from human donors. Unfortunately, such human AE (HAE) cells do not easily divide (expand) in vitro; this poses a large logistic and ethical problem for the researchers. Here, I summarize recent achievements in the methods for in vitro culture of human AE cells, with special emphasis on the conditionally reprogrammed cell (CRC) models, which allow longer and more effective expansion of primary human AE cells in vitro. The review describes how the specific chemicals used in the CRC models work to allow the increased HAE divisions and compares the effects of the different so-far developed variants of the CRC HAE culture. The review also pinpoints the areas which need to be refined, in order to maximize the usefulness of the CRC AE cultures from human donors in research on human airway disorders.

Keywords: Primary airway cell culture, Air-liquid interface culture, Conditional reprogramming, ROCK inhibitor, SMAD inhibitor, TGF- $\beta 1$ inhibitor

${ }^{*}$ Correspondence: zuzanna.bukowy-bieryllo@igcz.poznan.pl Institute of Human Genetics PAS, Strzeszynska 32, 60-479, Poznan, Poland

\section{Background}

Respiratory diseases, both environmentally-induced, such as chronic obstructive pulmonary disease, COPD, or asthma [1], and hereditary, such as cystic fibrosis (CF) original author(s) and the source, provide a link to the Creative Commons licence, and indicate if changes were made. The images or other third party material in this article are included in the article's Creative Commons licence, unless indicated otherwise in a credit line to the material. If material is not included in the article's Creative Commons licence and your intended use is not permitted by statutory regulation or exceeds the permitted use, you will need to obtain permission directly from the copyright holder. To view a copy of this licence, visit http://creativecommons.org/licenses/by/4.0/. The Creative Commons Public Domain Dedication waiver (http://creativeco mmons.org/publicdomain/zero/1.0/) applies to the data made available in this article, unless otherwise stated in a credit line to the data. 
or primary ciliary dyskinesia (PCD), affect the major part of present-day societies. Respiratory diseases are one of the most common causes of death globally [2] and pose a large burden to any healthcare system. Accurate diagnosis and efficient therapies of respiratory diseases require in-depth knowledge of their pathophysiology and underlying biology of the airway cell and tissue. Unfortunately, lack of appropriate models of differentiated respiratory epithelium and the insufficient cost-, time- and workload efficiency of the existing models make the basic and applicative studies of pathogenic processes associated with the respiratory diseases, a difficult and cumbersome task.

An effective model of a tissue has to fulfill a range of requirements: it has to be robust and consistent, costeffective and scalable. Moreover, it has to accurately represent the native tissue, in order to be relevant to the studied disease or condition [3]. Animal models of airway epithelium, including mouse or rat, are a robust source of the well-differentiated respiratory epithelium and thus, are often exploited in studies of respiratory diseases. However, due to a relatively small number of cells acquired from a single animal (e.g. mice or rat), such models are not fully scalable, and using a large number of animals per experiment poses an ethical burden. Moreover, larger animal models such as dogs, pig or cattle, require a considerably more space and have a longer life cycle, making these animal models less cost-effective. However, even the most cost- and time-efficient animal models, such as rodents, do not always fully represent the structure and physiology of the human respiratory epithelium. For example, the composition of airway epithelium in different areas of the respiratory system in mice differs from that in humans [3-5]. Moreover, some animal models might not always fully reflect the human symptoms. For example, in the animal model of PCD caused by lack of DNAH5 protein, mice lacking DNAH5 display hydrocephalus, which is not present in humans with DNAH5 mutations [6]. The difference between the animal and human models can lead to problems with recapitulating human symptoms in animal disease models, or to false positive results in animal studies, which later lead to therapeutic failures of clinical trials in humans [7]. Thus, animal disease models have to be chosen with care, taking into consideration the similarity in the structure and physiology between the animal and human tissues.

In vitro cultured primary human airway epithelial (HAE) cells seem to be the most adequate model for studies on the functioning of human respiratory epithelium in airway diseases. The successful application of HAE cultures from patients not only limits the use of laboratory animals, in agreement with the animal reduction policies. HAE cultures also advance work on the pathophysiology of the disease, allowing to explain some of the clinical symptoms in the patients, or the disease course $[8,9]$. HAE cultures are also essential for the diagnosis of airway syndromes notoriously difficult to diagnose (e.g. PCD) [10]. They are also essential for the development of personalized therapies, such as correction of mutations inducing premature termination codons (e.g. in the cystic fibrosis transmembrane conductance regulator protein, CFTR, in CF) [11, 12]. HAE cultures are also an adequate model to study host-pathogen interactions $[13,14]$, which has to be remembered in the light of the recent SARS-COV-2 pandemia.

Over the years, many different models of HAE have been developed, ranging from primary airway cell culture, through induced pluripotent stem cells (iPSCs), to immortalized cell lines (see below for details) [7, 9, 13]. However, not all these models fulfill the requirements for a good disease model [3] (see below for details). Here, I summarize recent achievements in the culture of HAE cells, with the special emphasis on the conditionally reprogrammed cell (CRC) models, which allow long-term expansion and differentiation of primary HAE cells, exceeding 4 passages. The review presents available HAE culturing platforms and describes the effects of several compounds, used in CRC HAE methods, on primary HAE cells' proliferation and differentiation. Other factors affecting the CRC HAE culture success, such as tissue sampling method, tissue origin, presence of the multi-ciliated cells (MCC) in the sample, donor's lifestyle and used medications are also described. The review also pinpoints the areas that need to be developed further, in order to maximize the usefulness of CRC HAE cultures in airway science.

\section{Human respiratory epithelium structure and differentiation in vivo}

Conducting airways, which extend from trachea to the proximal end of small bronchioles [15], are lined by pseudostratified respiratory epithelium (PSE). During morphogenesis, respiratory epithelium lining the airways is formed through gradual commitment of the definitive endoderm, to anterior foregut endoderm, lung epithelial progenitors and finally to distal airway or alveolar progenitors [16] (Fig. 1a).

Differentiated PSE is composed mainly of mature secretory (goblet) cells and MCC columnar cells contacting the airway lumen (luminal cells), as well as the basal cells (BCs), which rest on the basement membrane (basal lamina) $[17,18]$. Depending on the location in the airways, MCCs, mature mucus secretory cells, and BCs can comprise up to $60 \%, 10 \%$ and $6-30 \%$ of PSE cells, respectively [17-19]. Additionally, PSE also contains 
rare cells, such as tuft/brush cells, neuroendocrine bodies (NEBs) and pulmonary ionocytes [20,21]. Tuft cells and NEBs primarily serve as chemoreceptors and secrete neuropeptides, which may modulate the tissue microenvironment and innate immunity [20,22]. On the other hand, recently identified pulmonary ionocytes express high levels of CFTR and thus are probably responsible for the airway surface liquid regulation [23].

$\mathrm{BCs}$, which serve as stem cells of the PSE, constantly replenish the airway epithelium. Upon epithelial airway injury, BCs divide and give rise either to suprabasal cells (a.k.a.luminal progenitors), a common stage in goblet and MCCs differentiation, or directly differentiate into the tuft cells [24]. From tuft cells, ionocytes and NEBs are then formed [24]. Differentiating luminal progenitors give rise to a club cell, another common stage of goblet cells and MCCs differentiation [21]. Club cells may either directly differentiate to goblet cells, or give rise to deuterosomal cells, from which, differentiated MCCs are finally made [25]. Generally, such airway self-renewal is an ongoing, asynchronous process, induced by injury occurring to the different parts of the airway [26].

$\mathrm{BCs}$ are abundant in the whole human airways, with lower numbers in smaller airways $[17,21]$. BCs are characterized by high expression of TP63, CD44, increased expression of desmosomal proteins (KRT5, -6C, -14 and -15 [27], and low levels of Notch signaling proteins (NOTCH1, NOTCH ICD, DLL-1) [27, 28]. The first BC

a
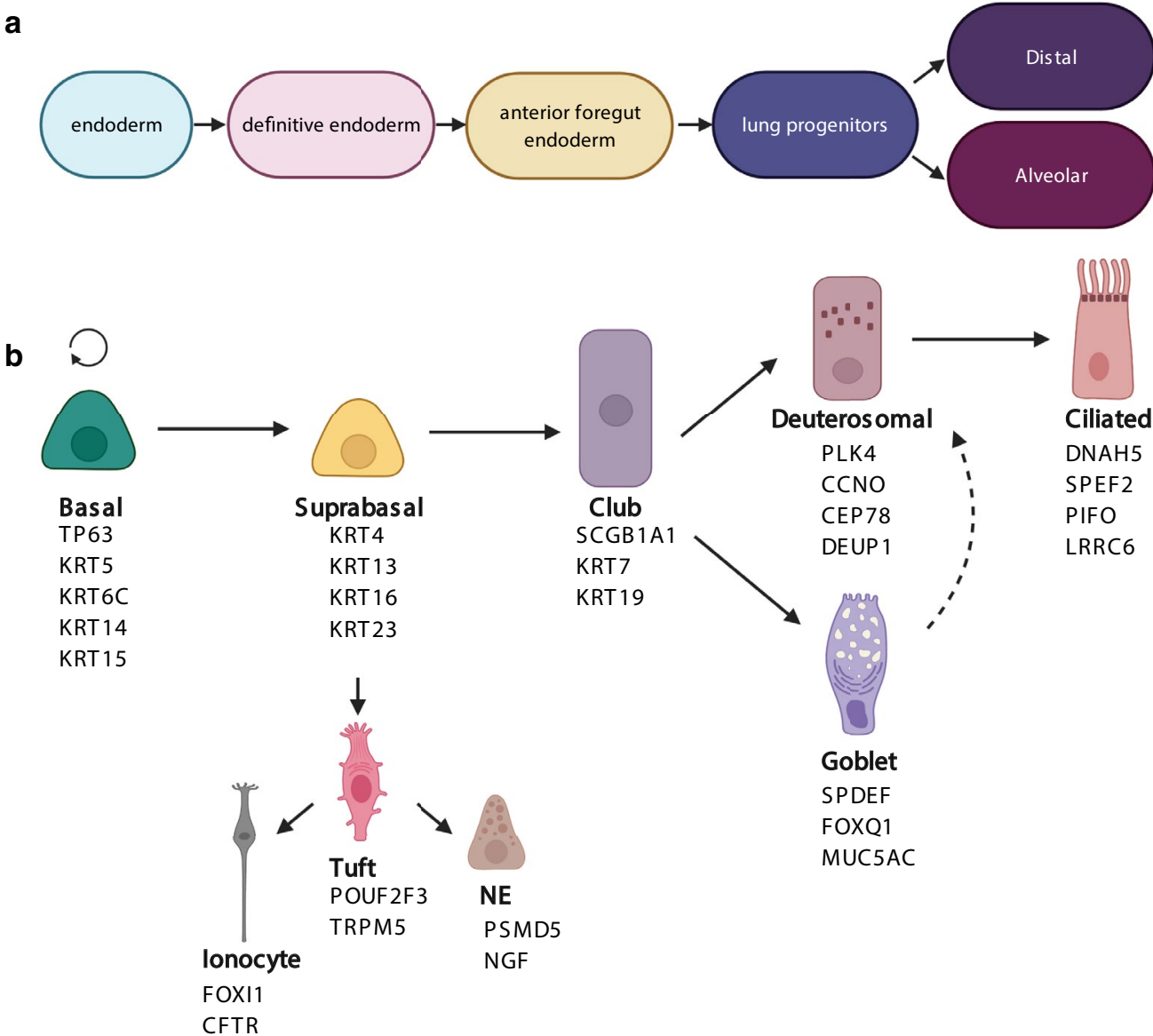

Fig. 1 Airway epithelial differentiation pathways. a Differentiation of airway epithelial cells during embryonic development. b Differentiation of airway epithelial cells after birth (from adult stem cells). Names below the different cell types are the markers of the specific cell types (based on recent human single-cell RNAseq studies [21, 24]). TP63, KRT5, KRT6C, KRT14 and KRT15 are basal cell markers, while supra-basal cells are characterized by expression of KRT4, KRT13, KRT16 and KRT23. Within the mucociliary lineage, club cells are distinguished by expression of Scgb1a1, KRT7 and KRT19, mature goblet cells have expression of SPDEF, FOXQ1 and MUC5AC. The deuterosomal cells express PLK4, CCNO, CEP78 and DEUP1, while mature ciliated cells are distinguished by the expression of DNAH5, SPEF2, PIFO and LRRC6. Suprabasal cells can give rise to tuft cells, which express POUF2F3 and TRPM5. These in turn can differentiate either to ionocytes, expressing FOXI1 or CFTR, or to neuroendocrine cells, expressing PSMD5 or NGF 
differentiation stage, suprabasal cell, is characterized by KRT16 and KRT23 expression [21]. Moreover, suprabasal cells may at the same time express KRT13, keratin found typically in the $\mathrm{BCs}$ and cells present in the basal layers of the epithelium, together with KRT4, characteristic for more luminal cells [21].

Differentiation of progenitors towards MCCs is associated with the expression of MCIDAS- CCNOMYB-FOXJ1 genes cascade [21, 29]. Progenitors differentiating towards goblet cells have high expression of SPDEF, FOXQ1 and MUC5AC $[21,26]$. Tuft cells, which serve as progenitors of NECs and ionocytes, are characterized by expression of POU2F3 and TRPM5 [22, 24]. After differentiation towards NECs or ionocytes, they acquire expression of PSMD5 and NGF, or FOXI1 and CFTR, respectively [20, 23] (Fig. 1b).

In the absence of $\mathrm{BCs}$, caused by e.g. $\mathrm{SO}_{2}$ exposure, upon airway injury, secretory cells are able to co-maintain club cell population, through transdifferentiation to MCCs [4, 21]. Also other cell types of PSE, such as neuroendocrine cells and myoepithelial cells from the submucosal glands, can serve as facultative progenitors in PSE [4]. In contrast, MCCs present in PSE are terminally differentiated and are not able to divide and yield progenitors [21].

\section{Primary airway epithelial cell culture}

First reports on the culture of airway epithelial cells come from the beginning of the 1980's. However, at that time, the HAE cell propagation and cell differentiation methods were inefficient and technically challenging, thus the use of these methods was limited [30]. Gradually, increased knowledge about the chemical and mechanical factors stimulating HAE cells to propagate or differentiate led to the improvement of the culturing methods, development of dedicated growth media and increased popularity of primary HAE cell cultures [31-34].

In vivo, cellular differentiation during homeostasis is an ongoing, asynchronous process [26]. However, in vitro, the cell expansion and differentiation steps are separated, supported by media containing culture-stage specific supplements (e.g. adequate $\mathrm{Ca} 2+$ or retinoic acid, RA, levels) [30, 35]. Also mechanochemical conditions (e.g. contact with atmospheric air, and/or specific stiffness of the substrate, the cells grow in), and the composition of the cellular microenvironment (presence of the extracellular matrix, ECM, molecules), significantly influence the growth and differentiation of airway epithelial cells in cell culture [36].

With time, several culture platforms were developed, such as air-liquid interface culture (ALI) or adherentsuspension culture [31, 37, 38]. Each of these culturing platforms requires stage-specific media and supplements.
These can either be prepared in the lab, according to the developed protocols [33, 39], or acquired commercially (BEGM, UltroserG, Epithelix). Currently, culture of primary HAE cells is a frequently used model for research on tissue development, inborn or acquired airway diseases and host-pathogen interactions.

\section{Advantages and limitations of traditional primary AEC culture}

The most important advantage of the primary HAE cell culture from patients, in the context of studying the pathogenesis of the inherited respiratory diseases, is that they provide a source of respiratory cells already containing genetic modifications, without the need to genetically modify the cells in the laboratory. This also encompasses epigenetic modifications-it has been shown that cultured primary airway cells from COPD patients reflect epigenetic DNA changes and replay epithelial reactions to IL-13 $[9,40]$. Also in vitro differentiated cells from asthma patients retain characteristics of the distorted airway epithelium in culture, which is important for the studies of environmentally-induced airway disorders [41, 42].

In contrast, iPSCs often lose epigenetic marks [7, 43]. They are also tumorigenic and show genetic instability, which is an important obstacle in the gene therapy and tissue regeneration approaches [42, 44, 45]. Moreover, high costs and long-term derivation of the iPSCs into airway progenitors make the iPSC model less favorable, compared to the primary HAE models.

Primary HAE cultured cells are also a better model than immortalized airway cell lines. Although immortalized airway cell lines have a long proliferative lifespan, are cost-effective and show consistent results (as usually are derived from one donor), the immortalization may reduce the ability of cells to differentiate. In effect, the structure and physiology of airway cell lines do not always reflect the structure or physiology of the native epithelium. The airway cell lines may lack, for example, mucociliary differentiation, barrier formation or expression of specific receptors required for the virus infection $[42,46]$. This makes the airway cell lines less suitable for studies of airway disorders related to cilia (e.g. PCD), mucus (e.g. CF), or viral entry [46]. However, cell lines still can be used for studies requiring the presence of polarized epithelium, including innate immunity, ion physiology or therapeutic approaches [47, 48].

Unfortunately, there are also several disadvantages of the traditional primary HAE culture, which for some time have prevented a broader use of this type of culture in the airway cells research. The main and most significant drawback of primary HAE cells is their limited ability to efficiently proliferate and differentiate in vitro for a 
larger number of passages. Under normal circumstances, primary HAE cells are able to efficiently divide during only for 3-4 population doublings[49, 50]. After that time, the cells start to divide slower, and gradually lose the ability to form cilia, produce mucus or express tight junction proteins, [50-52]. Obtaining sufficient number of differentiated cells in culture is therefore very difficult, especially in light of the limited availability of tissues/cells (acquired from biopsies or brushings). Moreover, the primary HAE cells may not differentiate very well after cryopreservation, which limits the possibility of later use of stored patients' samples [53]. In effect, experiments, which require long-term culturing, such as genetic modifications of primary HAE cells, when performed under regular culture conditions, without the addition of factors prolonging the cells' lifespan, represent a cumbersome and time-consumming task.

Other disadvantages of primary airway epithelial cultures is the frequent lack of consistency or robustness [42]. This might be due to the sampling method, intrinsic differences between the donors (more on this below), but also type of the culture and media used. All these disadvantages contributed to a not very frequent use of the primary HAE cell cultures. This has changed in the recent years, especially after the development of the CRCs cultures.

\section{Culturing platforms for primary HAE cell culture}

Different culture platforms exist to culture and differentiate primary HAE cells. One of the oldest cell culture types is the adherent $2 \mathrm{D}$ culture, where the HAE cells are cultured as a single layer, submerged with growth medium. The adherent 2D culture promotes an undifferentiated HAE phenotype, thus it is mostly used for the expansion of HAE BCs (Fig. 2). To improve the adhesion of the HAE cells to the culturing vessels, thin collagen coating or a thicker layer of collagen gel can be used [33, 37].

Several platforms have been developed, which support successful in vitro mucociliary differentiation of HAE cells (Fig. 2). The presently most common differentiation platform is the air-liquid interface (ALI) culture, where dissociated HAE cells are first expanded in submerged culture and then differentiated on a porous membrane insert $[33,54]$. After seeding to culture inserts, HAE cells are cultured submerged in the medium, as the medium is added both to the insert inside (apical chamber), and to the well below the insert (basolateral chamber). Upon confluency of the cellular monolayer, differentiation medium is changed to a specific ALI differentiation medium, which is added only basolaterally, and the apical chamber of the insert, together with the cell layer, is exposed to the atmospheric air [33]. During differentiation, the cells in ALI platform develop a typical PSE structure, with non-dividing basal epithelial cells staying close to the insert membrane, and the MCCs and goblet cells oriented towards the air [33] (Fig. 2). The single layered PSE structure allows the ALI cultures to be easily used for the analyses of ion/ drugs transport and measurements of the transepithelial resistance (TEER). However, the differentiation in ALI is sensitive to culture conditions, changes in air humidity, and the differentiation process depends much on the amount and quality of the HAE cells seeded [32]. Differentiated HAE cells can also be obtained in 3D culture, when groups of the expanded HAE BCs are cultured in suspension culture or embedded in ECM matrix [34, 38, 55, 56].

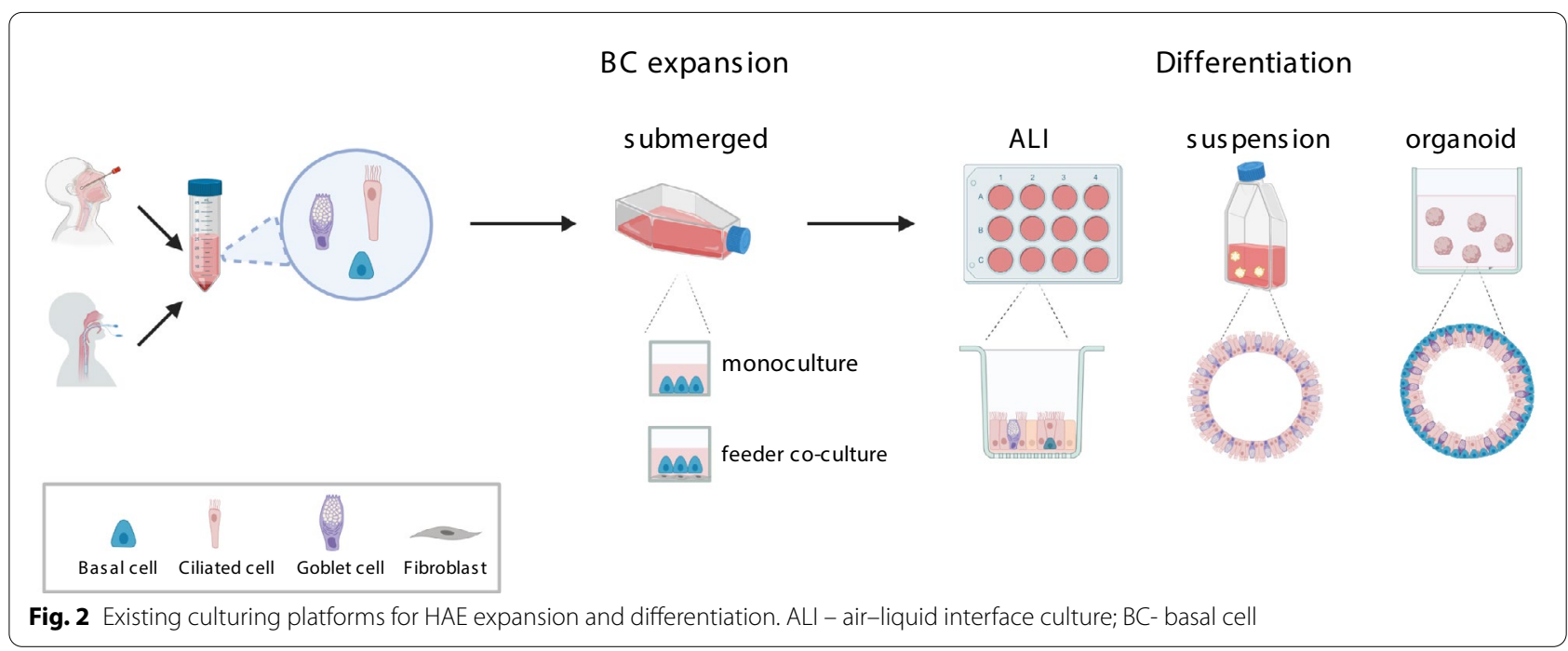


The suspension differentiation of HAE cells has been the basis of the adherent-suspension culturing method, developed by Jorissen [34]. In the adherent-suspension method, cells are first cultured adhered to a collagen gel [34]. Upon confluence, collagen gel layer is digested, and the sheet of confluent cells is transferred to rotating suspension flasks for differentiation. During suspension culture, within 15 days, cell sheets close into spheres (spheroids), which contain goblet and MCCs on the spheroid outer surface (Fig. 2). Differentiation of primary HAE cells in the $3 \mathrm{D}$ suspension culture proceeds faster than in ALI $[34,54,57]$, however, the adherent-suspension culture method has a limited scalability, as the primary HAE cells grown on collagen gel layer cannot be dissociated to be further expanded in another vessel.

Moreover, the differentiation of the spheroids in the suspension culture is more asynchronous and depends on the size of the spheroid in question [34]. Some studies have also shown, that differentiated spheroids might not contain BCs, which makes the spheroids grown in suspension not able to self-renew [58].

An alternative method of culturing and differentiating HAE cells in 3D is the recently developed organoid culture [55]. Dissociated primary HAE cells are embedded in a 3D ECM matrix in the presence of media containing tissue self-renewal promoting compounds known from the stem cell research (noggin, inhibitors of the Bone Morphogenetic Protein, BMPi or ROCK proteins, ROCKi, etc.). Upon embedding in the ECM matrix, primary HAE cells start to divide and self-organize to form aggregates, which gradually differentiate into sphere-like organoid structures. In the organoid structures, goblet and MCC cells are facing towards the organoid lumen and the basal stem cells face the outer surface of the organoid (Fig. 2). Due to the presence of basal epithelial stem cells, the organoids are able to self-renew and the organoid cultures can be efficiently proliferated through organoid disruption for a long-time (>1 year) [59, 60]. However, the 3D structure of the organoids make this culturing platform not suitable for some forms of analyses, e.g. ion function measurements by TEER. Moreover, the size of the organoids is difficult to control, which makes it less suitable for high-throughput analyses and not as reproducible as the ALI culture [3, 44].

\section{CRC models of HAE}

The recent development of CRC technique, which allows prolonging the limited lifespan of the cultured cells, revolutionized the primary HAE cell culture. The CRC approach exploits the use of inhibitors of the Rho-associated coiled-coil-containing protein kinases 1 and 2 (ROCKi) [28, 61]. Rho kinases are small GTPases, which play role in cell-cell adhesion, cell migration, differentiation, apoptosis and proliferation [61].

One of the known ROCKi, Y-27632, has been shown to increase survival of embryonic stem cells (ESCs) in vitro [62]. ROCKi Y-27632, added to the difficult-to-proliferate keratinocytes, traditionally cultured in the presence of lethally irradiated mouse fibroblast feeder 3T3-J2 cells, rapidly changed keratinocyte morphology and induced robust proliferation, providing a nearly infinite source of undifferentiated keratinocytes [63]. Once the ROCKi and the feeder cells were removed, keratinocytes could later be efficiently differentiated, hence the term "conditionally reprogrammed cells" (CRCs) was coined. Further experiments have shown, that this mechanism is effective also in other types of non-keratinocyte epithelia, including HAE cells $[28,61,64]$ (Table 1 ).

The increased proliferation of HAE cells in the CRC culture massively affected the culture yield [27, 28, 65], with 20-fold increase in cell numbers within $96 \mathrm{~h}$ [28]. The high replicative potential of CRC HAE culture, starting from a nasal brushing, could yield in less than 4 weeks cell numbers sufficient to cover a human trachea regeneration scaffold $\left(>1 \times 10^{7}\right.$ cells) [66]. The increased proliferation did not cause any negative effects on the cultured CRCs-the CRCs maintained a stable karyotype, the contact inhibition ability and were non-tumorigenic $[28,66]$. Importantly, the CRC conditions also promoted increased transduction and electroporation [61, 67], without negative effects on HAE cell proliferation or differentiation $[61,68]$. The increased proliferation of HAE cells in the CRC culture supported single cell cloning and allowed antibiotic selection of the transduced cell population [28]. This opened the possibility of efficient genetic modifications of primary HAE cells using reporter plasmids [61] or Cas9 nucleases [67, 69]. ROCKi also allowed efficient reinitiation of the HAE cultures after cryopreservation [61]. Generally, addition of ROCKi and feeder cells made primary HAE cultures a more complete and efficient tissue model for airway studies.

However, the CRC HAE conditions with the use of feeder cells (CRC HAE co-culture) were not fully universal and applicable to all types of experiments. For example, it has been shown, that the CFTR function can decline with subsequent passages of the CRC HAE co-culture [70]. To remove that limitation, CRC HAE co-culture at reduced oxygen concentration $\left(2 \% \mathrm{O}_{2}-7 \%\right.$ $\mathrm{CO}_{2}-91 \% \mathrm{~N}_{2}$ mixture) has been explored [69]. The reduced oxygen conditions not only allowed to obtain differentiated HAE cells with functional CFTR reactions even at P10, but also limited cellular stress, extending the proliferative lifespan of primary HAE cells above 100 PDs, compared to the regular CRC HAE co-culture conditions [69]. In addition, upon differentiation in ALI, 


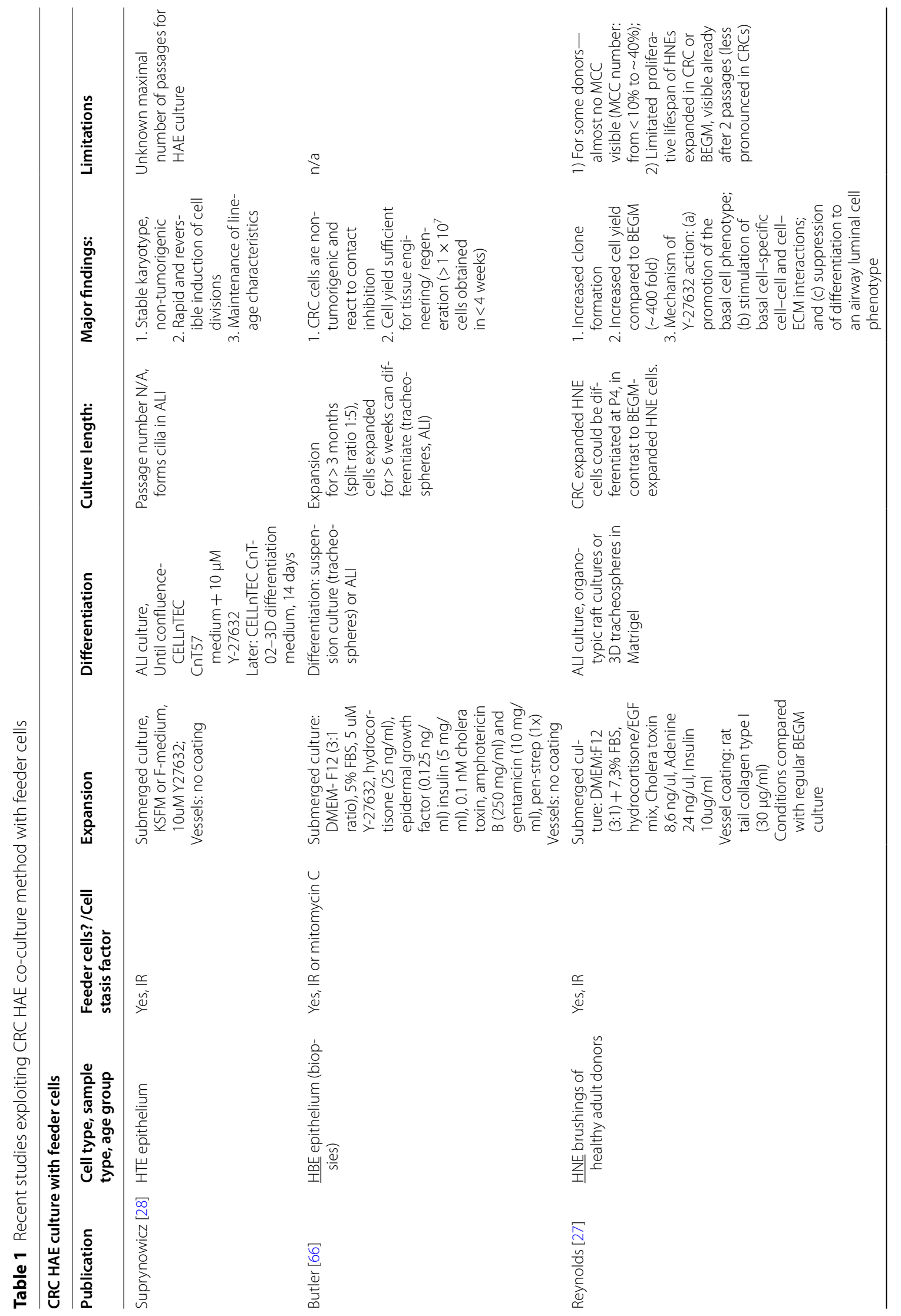




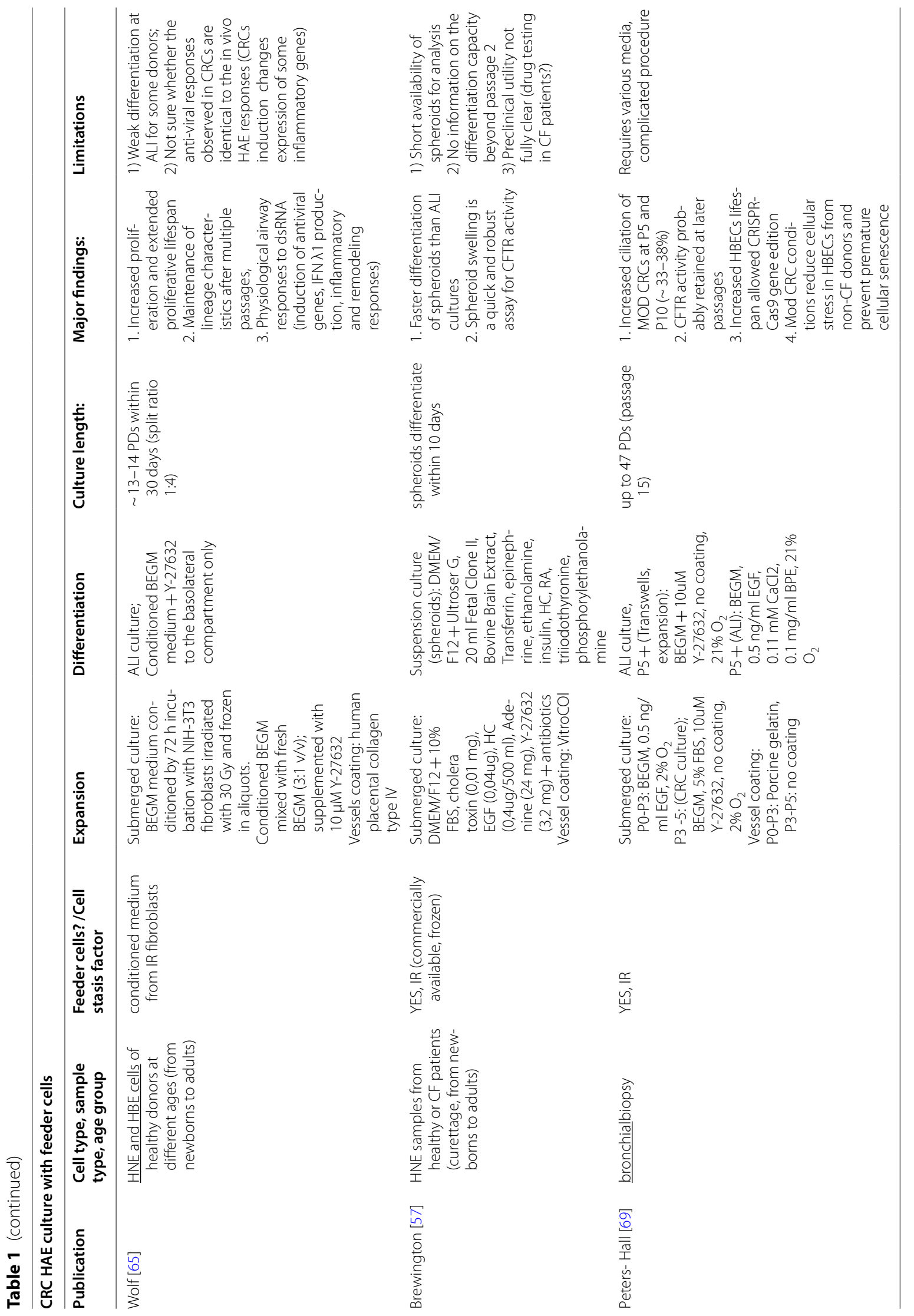


HAE cells expanded in low-oxygen CRC co-culture generated PSE containing more MCC cells, compared to regular BEGM and standard CRC HAE co-culture conditions [69] (Table 1).

Addition of ROCKi to the primary HAE cells quickly induced the adult stem cell phenotype (Fig. 3), associated with increased expression of stem cell markers p63 and CD44, upregulated desmosomal adhesion proteins typical for BCs (upregulated: Krt10, desmoplakin, claudin 10, cadherin 3). ROCKi also inhibited the transition to the luminal airway progenitor phenotype, by repressing signaling pathways (Notch 1 signaling, Notch 1 receptor, Notch ICD, DLL-1), cell-cell interaction molecules (claudin10,11 and occludin) and protease genes (MMP 2,9,14 and 28) typical for the luminal progenitor cells [27, 28]. This led to undifferentiated HAE cell state and longer BCs proliferation [27, 28] (Fig. 3).

The high replicative potential of HAE cells obtained using CRC co-culture method was sufficient to generate $\mathrm{HAE}$ cell numbers useful in tissue regeneration [66]; however, the CRC co-culture conditions contained animal origin components, which potentially put a risk to the patient during the transplantation procedures. The increased knowledge of factors influencing airway epithelial cell differentiation allowed modification of the CRC HAE culture method, to avoid the use of 3T3 murine feeder cells (CRC HAE monoculture method) (Table 2).

Mou and coworkers have reported that SMAD/TGF- $\beta$ signaling is active in differentiating HAE cells and absent in basal HAE cells [71]. Addition of two inhibitors of SMAD pathway effectors TGF- $\beta$ and ALK2 (A-83-01 and DMH-1, respectively), to the growth medium containing ROCKi Y-27632 allowed efficient expansion of primary

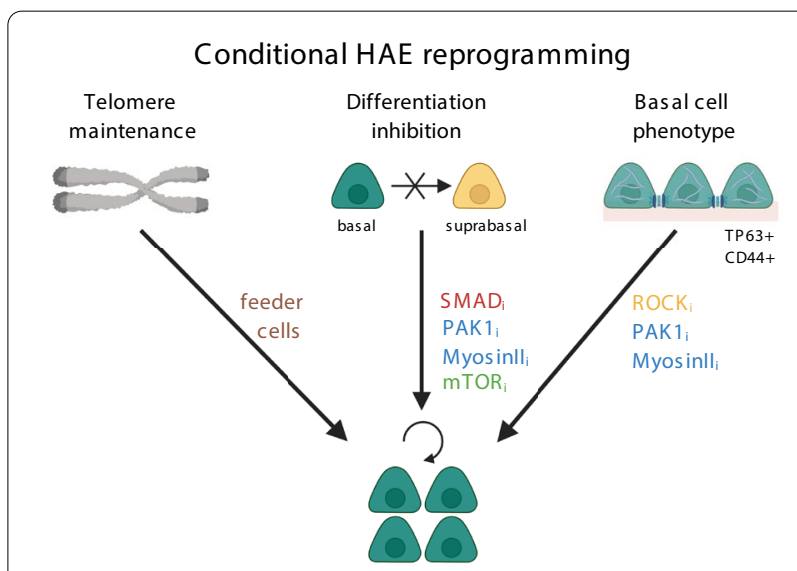

Fig. 3 Mechanisms of conditional HAE reprogramming allowing proliferation of basal cells. ROCKi - ROCK inhibitor, PAK1i - PAK1 inhibitor, Myosin Ili- inhibitor of Myosin II, SMADi - inhibitor of SMAD, mTORi - inhibitor of mTOR pathway
HAE cells. This was possible through the inhibition of the $\mathrm{BC}$ differentiation towards luminal progenitors cells [71] (Fig. 3). The HAE expansion persisted until HAE passage 25-30 ( 80 PDs), without induction of telomerase (hTERT) expression. Thus, upon telomere erosion, cells abruptly stopped propagation. Despite efficient proliferation, the characteristics of the differentiated airway epithelium were not consistent-MCC cell differentiation declined after P10, but physiological CFTR reactions were retained only until P8 [71] (Table 2).

The influence of SMAD/ROCK inhibitors on airway BCs' proliferation was also confirmed by Zhang and coworkers, who identified SMAD and ROCKi as independent factors in a screening assay of small molecules able to affect HAE BCs proliferation [72]. Further optimization of the SMAD/ROCKi method by the use of inhibitors of downstream ROCK effectors, PAK1 (p21- associated kinase) or Myosin II, and reduction of the differentiation-inducing $\mathrm{Ca}^{2+}$ levels in the culture medium (EpiX medium) increased BCs' proliferation even more, mainly through the inhibition of the differentiation towards basal luminal progenitors (Fig. 3). The inhibition of the ROCKSMAD-PAK1/Myosin axis allowed efficient cell proliferation of primary HBECs until 45-60 PDs (12-16 passages) [72]. Generally, this particular CRC method lead to over $1,000,000$ fold increase in HAE cell numbers, without the use of the feeder cells. However, cellular senescence was not avoided, as large cells increasingly accumulated from passage to passage [72] (Table 2).

Mammalian target of rapamycin (mTOR) pathway is important for the proliferation of airway $\mathrm{BCs}$, however the activation of mTOR pathway also induces HAE differentiation [73] (Fig. 3). Under repeated or chronic damage, constant mTORC1 activation leads to the reduction in the numbers of the airway $\mathrm{BCs}$ and the regenerative capacity of the airway [73]. Use of mTOR inhibitor (mTORi), rapamycin, combined with SMAD and ROCK inhibitors (A-8301 and Y-27632) successfully supported expansion and growth of human neonatal tracheal epithelial cells from aspirates [74], which contained very low initial number of cells $(<100$ cells/aspirate). The triple inhibition supported growth of expanded cells for at least 15 passages ( 45 PDs). During the culture, cells consistently expressed BCs markers and efficiently differentiated even at passage 16 [74]. Rapamycin did not induce or inhibit genes involved in oxidative stress, epithelialmesenchymal transition, or cellular senescence (Table 2).

\section{Media and vessel coating for HAE proliferation}

Generally, most of the CRC HAE feeder co-cultures use the original F-medium for keratinocytes published by Liu et al., but some studies have also successfully used BEGM medium for that purpose $[64,69]$. In some cases, BEGM 


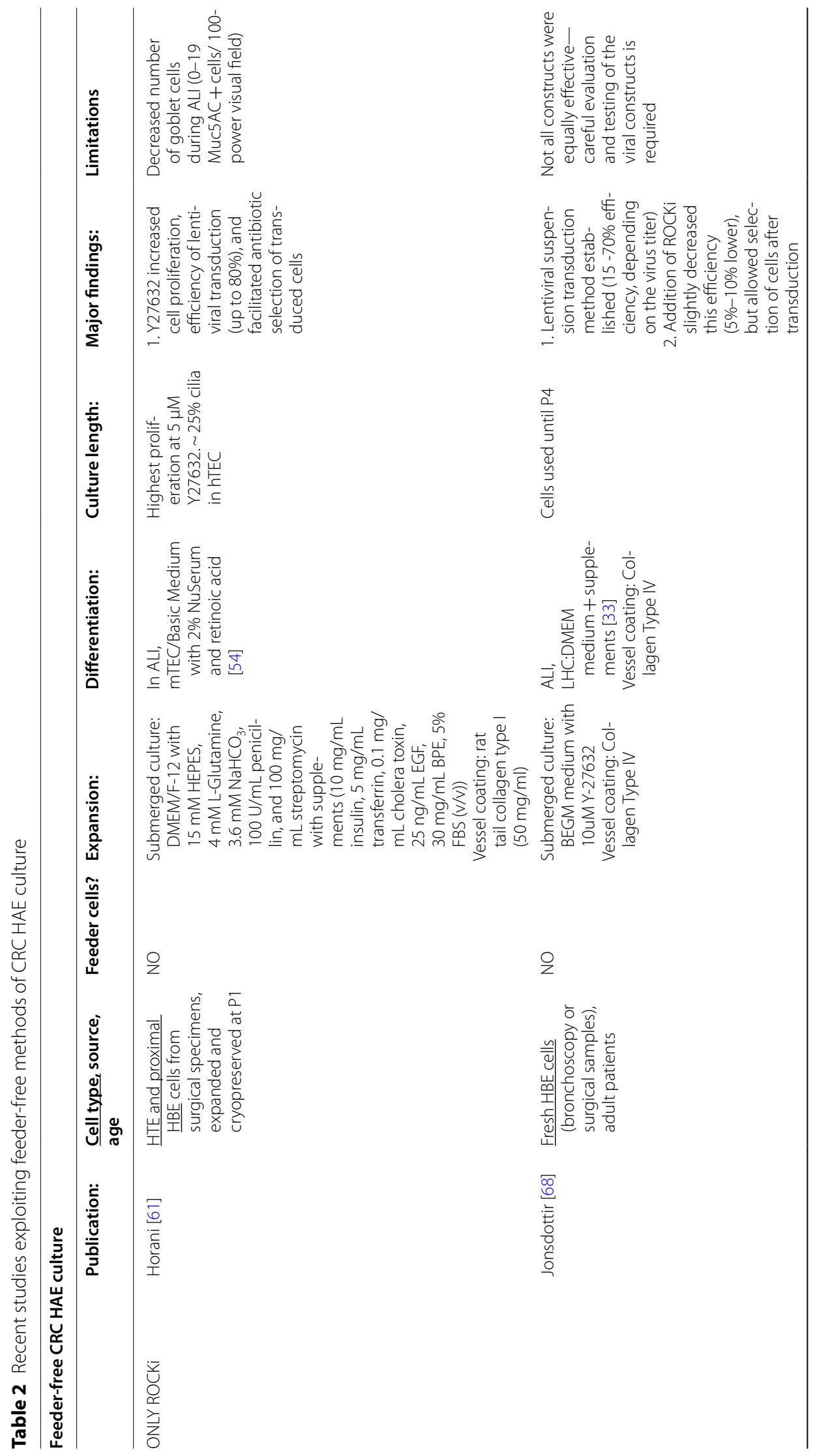




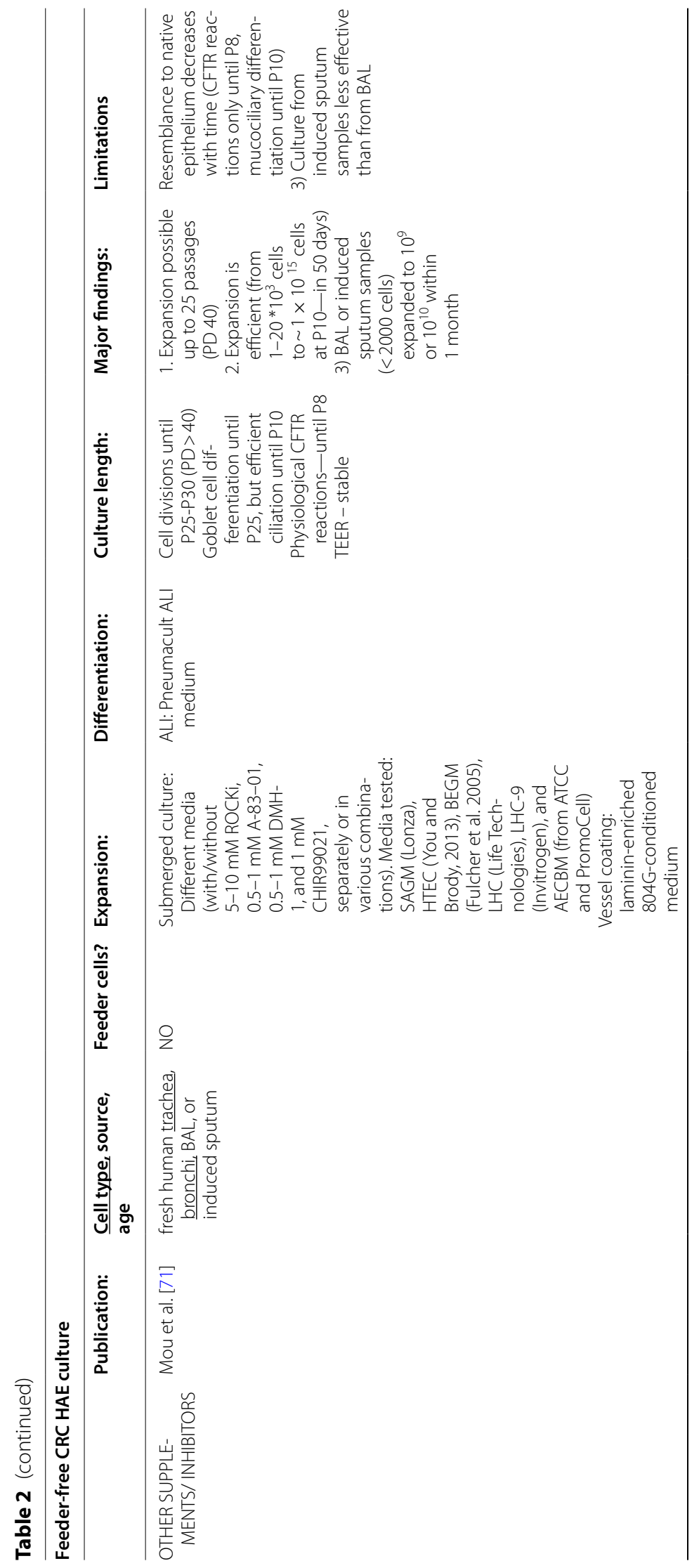




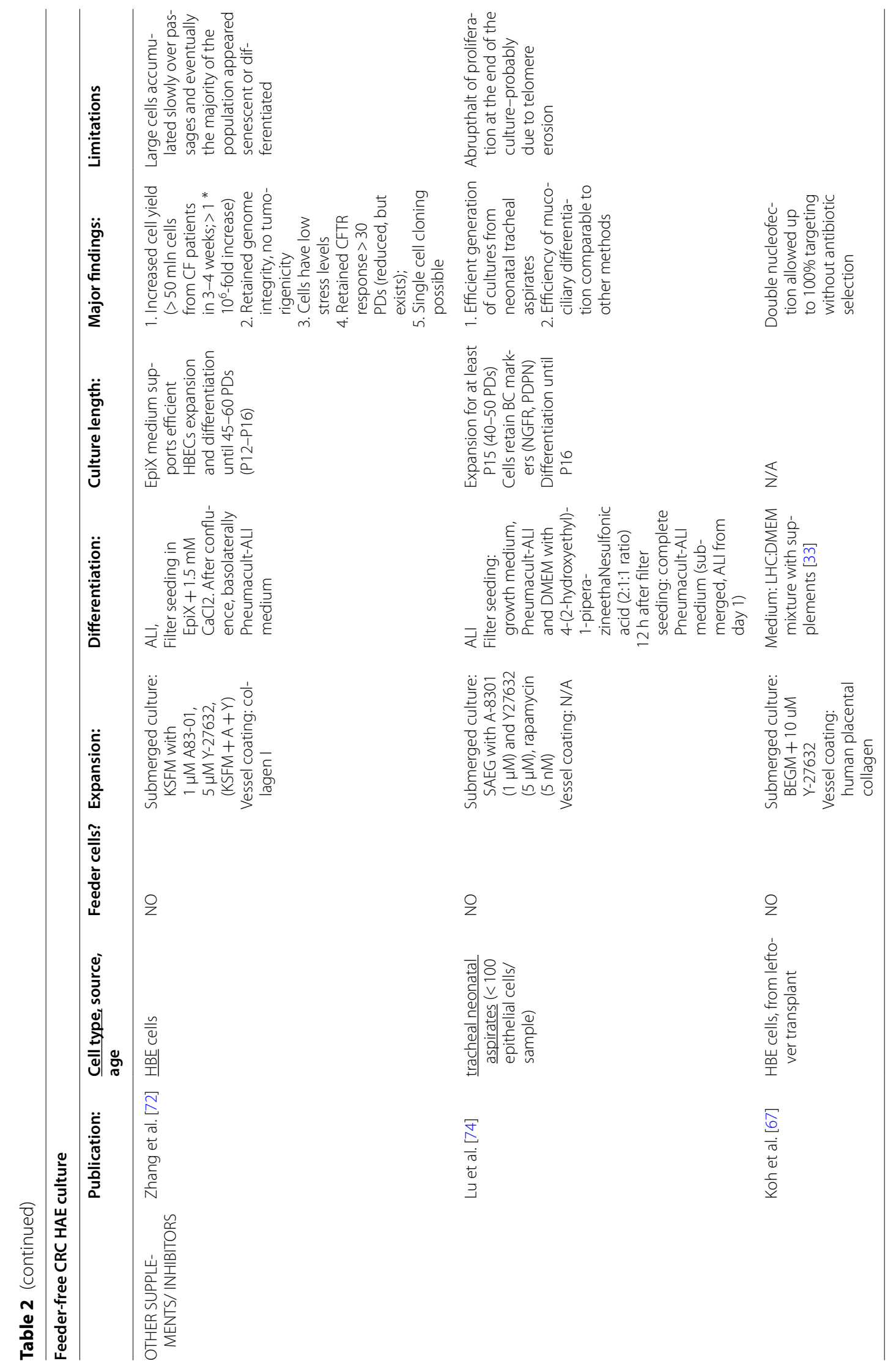


conditioned by incubation with lethally irradiated feeder cells was added to the HAE cell monoculture [65]. However, the effect of such conditioned medium on cell proliferation was not as effective, as direct co-culture with irradiated feeder cells.

Studies have shown that a range of growth media can be used for the CRC HAE monocultures, (F-medium, BEGM, SAGM, HTEC or LHC-9 media), as long as the media contain the appropriate inhibitors inducing the CRC state (ROCKi, SMADi, mTORi, PAK or myosin II inhibitors) $[61,67,68,71,74]$. However, the largest HAE expansion and best long-term effects were observed in the KSFM medium, which contains low levels of calcium, additionally preventing the differentiation of the BCs [72]. Regarding the culture vessels, most of the CRC HAEs studies continue to use culture vessels coated with basement matrix molecules, such as collagen (type I or type IV) [27, 57, 61, 65-68, 72]. Rarely, solutions containing laminin [71, 74], or porcine gelatin [69] were used. For HAE differentiation, most published studies have also used ALI platform, with classic home-made [33, 54], or commercially available HAE differentiation media (BEGM, Pneumacult-ALI, CELLnTEC, Vertex ALI, Epithelix + 1,5 $\left.\mathrm{mM} \mathrm{Ca}^{2+}\right)[57,65,69,71,72,74]$.

\section{Experimental considerations for the CRC HAE culturing methods}

In general, both CRC HAE regimens are rather similarthey robustly enhance HAE proliferation, leading to an increased cellular yield. The expanded HAE cells most often effectively generate differentiated HAE containing MCC and goblet cells and displaying ion function (e.g. CFTR activity). In most of the cases, applied CRC HAE culturing methods do not have a large influence on the differentiation potential of expanded basal cells, and the exact numbers of MCC and goblet cells in the differentiated epithelium depend rather on the donor, the cellular passage and the type of medium used for differentiation (compare Tables 1, 2). In this context, the only exception was the method by Peters-Hall et al., where the airway BCs were expanded at reduced oxygen pressure $(2 \%$ oxygen) [69]. Differentiation of such BCs in ALI yielded differentiated epithelium with increased amount of ciliated cells compared to the normal oxygen conditions. Low oxygen levels are known to prevent differentiation of MCCs and some studies show that hypoxia may also promote the secretory (goblet) cell phenotype [75]. Increased ciliation after the differentiation of BCs expanded under hypoxic conditions may have been a result of a larger pool of club cells, common stage of goblet cell and MCCs differentiation. Alternatively, an improved ability of the $\mathrm{BCs}$ to differentiate into different lineages (increased stemness) is responsible for this effect.
Due to the logistics related to preparation of the growth-inhibited feeder cells (seeding, irradiation/ mitomycin treatment), the workload in the CRC co-culture method is much higher than in the CRC monoculture [76]. Although the amount of work can be reduced by the use of commercially available frozen irradiated feeder cells [27], the work related to the differential cell trypsinization of the feeder and HAE cells still remains. To reduce this workload, some studies have tested the possibility of using growth medium conditioned by the incubation with irradiated feeder cells, but this approach was not as efficient as the direct co-culture with feeder cells [65]. Moreover, another drawback of the CRC co-culture method is the potential contamination of CRC-expanded HAE cells with animal-origin feeder cells, which makes the co-culture CRC HAE method not suitable for human therapy [71].

The CRC HAE monoculture method does not suffer from that limitation and can be used in human therapeutic applications. Compared to the CRC HAE co-culture, the CRC HAE monoculture uses more chemically-defined growth media. Moreover, the expanded HAEs have slightly longer proliferative lifespan (45-60 PDs) and display slower decline in CFTR activity with passages (p8 vs p5 in the CRC HAE co-culture) [50, 71]. However, recent results indicate, that the CRC monoculture-expanded HAE cells might display different physiology, compared to HAE cells expanded using the co-cultured CRC method [77]. This includes reduced beating frequency of airway cilia and the lower ion currents than the ALI-differentiated HAE cells, expanded using the co-culture CRC method [77]. In that aspect, the monoculture CRC method might not as accurately represent the native epithelium as the co-culture CRC HAE method.

Therefore, the choice of the particular CRC HAE method should depend not only on the available equipment and workforce, but also on the particular experimental application of the CRC HAE cultures (Fig. 4). While benefits of the CRC HAE monoculture in immunology and human therapy applications are obvious, the choice of the particular CRC HAE culturing method for studies of ciliary beating or airway ion currents will depend on the preferred experiment time-frame or CBF intensity (Fig. 4). The CRC HAE proliferation method most suitable for other experimental applications is yet to be determined (Fig. 4).

\section{Other factors affecting primary HAE culture success}

Sampling method

Apart from the media composition, there are other factors, which influence the success of primary airway 


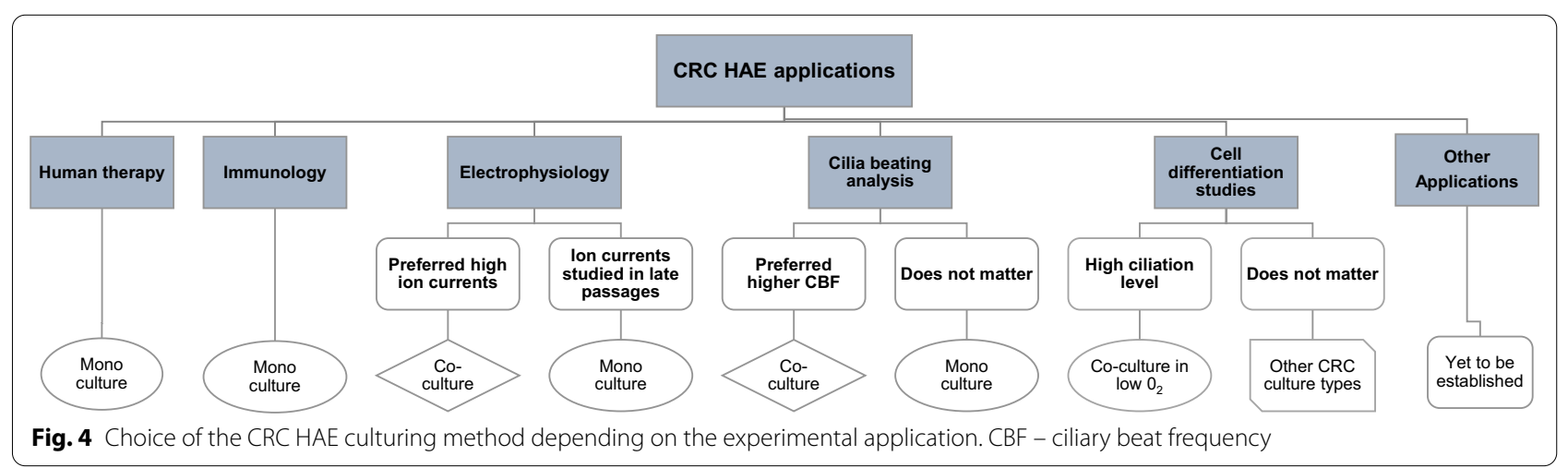

epithelial culture. As only $10-30 \%$ of the collected cell number are the $\mathrm{BCs}[17,19]$, successful culture should contain the highest possible number of airway cells, in the best possible condition. This depends very much on the effectivity and quality of the tissue sample, but also the donor's infection history, received medications and lifestyle factors.

The number and quality of cells in the epithelial sample are most important for the successful initiation of the airway epithelial cell cultures. The highest initial number of primary HAE cells can be obtained from tissues obtained via resection, transplantation or autopsy. However, these procedures are highly invasive, thus the supply of the tissues can be limited. Alternative collection methods, such as nasal or (nonbronchoscopic) bronchial brushings, are simple, quick, minimally invasive and can be performed even at the young age $[49,50]$. Brushings can also yield relatively high initial cell numbers (nasal brushing: up to $1.5 \mathrm{mln}$ cells, bronchial brushings $2.5-3.5 \mathrm{mln}$ cells/ two brush passes $[19,78]$, leading to a relatively high culture success rate (Table 3 ) $[19,49,50]$.

In contrast, isolation of HAE cells from induced sputum or bronchioalveolar lavage (BAL) samples yields much less cells $(<2000)$ (Table 3$)$, but these methods are completely non-invasive, and can be performed even in neonates [71]. Interestingly, despite similar initial cell numbers, cell cultures from induced sputum have lower culture initiation rate, than cultures established from BAL (Table 3). Successful primary HAE cultures can also be established from tracheal aspirates from intubated infants [74]. Such samples contain extremely low initial number of cells ( $<100$ cells/aspirate), but due to the fact, they can be collected multiple times a day, the rate of culture initiation is relatively high (Table 3 ).

Table 3 CRC HAE culture cell yield and success rate depending on the tissue collected

\begin{tabular}{|c|c|c|c|c|c|}
\hline Sampling method & Age group (condition) & Initial cell number & Subculturing method & $\begin{array}{l}\text { Success rate in } \\
\text { propagation }\end{array}$ & References \\
\hline Induced sputum & Children & $<2000$ cells/ portion & $\begin{array}{l}\text { CRC HAE mono (Rho/ } \\
\text { SMAD inhibition) }\end{array}$ & $20 \%$ in CF patients & Mou et al. [71] \\
\hline Tracheal aspirate & Neonatal & < 100 cells/ aspirate & $\begin{array}{l}\text { CRC HAE mono (Rho/ } \\
\text { SMAD/mTOR inhibi- } \\
\text { tion) }\end{array}$ & $\begin{array}{l}\text { 40\% from single sample, } \\
80 \% \text { if multiple sam- } \\
\text { ples/ patient }\end{array}$ & Lu et al. [74] \\
\hline $\mathrm{BAL}$ & Neonatal & $<2000$ cells/ portion & $\begin{array}{l}\text { CRC HAE, mono (Rho/ } \\
\text { SMAD inhibition) }\end{array}$ & $\begin{array}{l}\text { 100\% (multiple samples/ } \\
\text { patient) }\end{array}$ & Mou et al. [71] \\
\hline Nasal brushing & N/A (CF or healthy) & $\begin{array}{l}0.4 \text { to } 1.5 \text { million viable } \\
\text { cells }\end{array}$ & Traditional ALI culture & $\begin{array}{l}\text { Culture initiation: CF } \\
\text { patients-66\%; } \\
\text { healthy-85\% } \\
\text { Differentiation in ALI: } \\
\text { 100\% }\end{array}$ & Schogler et al. [78] \\
\hline Bronchial brushing & $\mathrm{N} / \mathrm{A}$ & $\begin{array}{l}0.045-0.2 \mathrm{mln} \text { cells/ } \\
\text { brush }\end{array}$ & $\begin{array}{l}\text { Indirect CRC HAE co-cul- } \\
\text { ture: HAE cells cultured } \\
\text { with conditioned } \\
\text { fibroblast medium } \\
\text { with ROCKi }\end{array}$ & $\mathrm{N} / \mathrm{A}$ & Wolf et al. [65] \\
\hline $\begin{array}{l}\text { Bronchial brushing } \\
\text { (non-broncho- } \\
\text { scopic) }\end{array}$ & $\begin{array}{l}\text { Children (healthy or } \\
\text { asthmatic) }\end{array}$ & $\begin{array}{l}\sim 2,67 \mathrm{mln} \text { cells/ } 2 \text { brush } \\
\text { passes }\end{array}$ & $\begin{array}{l}\text { CRC HAE co-culture, } \\
\text { direct }\end{array}$ & $\mathrm{N} / \mathrm{A}$ & Martinovich et al. [50] \\
\hline
\end{tabular}




\section{Sample- and donor-related factors}

During the culture initiation, mucus should be avoided, as it poses a source of contamination to the cultures and can lead to the failure of culture [32]. In the case of CF patients, specific cocktails of antibiotics (and sometimes also mucus-releasing factors) are employed at the beginning of the culture, to ensure proper removal of mucus and sterility of the culture from the start $[78,79]$. Moreover, collected cells, no matter the number, should be in the best possible condition. A marker of a good sample condition is the presence of MCC cells, as they often first react to airway insults [80]. Studies have shown, that culture success rate in ALI setting is $\sim$ two-fold lower for samples, which do not contain MCC cells in the initial biopsy $(\mathrm{OR}=2.18,[1.50-3.16], \mathrm{p}<0.001)$ [80]. Outcome of the culture depends also on several donor-related factors, such as lifestyle and used medications. It has been observed that frequent inflammation and smoking reduce the proliferative potential of epithelial stem cells, and yield differentiated epithelium with the smaller number of club cell progenitors expressing SCGB1A1 [9]. The use of inhaled corticosteroids or long acting $\beta$-agonist should be avoided, to increase the culture success [80] $(\mathrm{OR}=\sim 0.62-0.64 ; p=0.01$ or $\mathrm{p}=0.02$, respectively). Also some donor's disorders (e.g. dry nose) can cause considerable difficulties in collecting sufficient number of cells for starting an effective culture (Bukowy-Bieryllo, unpublished observation). Furthermore, care should also be taken, when collecting the primary HAE cells, as local anesthetics and some inhaled drugs (e.g. lidocaine or hypertonic saline) can significantly reduce the cilia motility (lidocaine being least toxic) [81-83], and should thus be avoided.

\section{Tissue source}

Another factor, which needs to be considered when planning experiments using primary airway cell culture, is the airway region, from which the tissue originates. Traditionally, the majority of studies use distal airway cells (bronchial or tracheobronchial epithelial cells) to initiate the culture, due to their established culture methods and availability in patients with respiratory disorders (regular bronchoscopies). However, cultures of cells from proximal airway (nasal epithelium, HNE) are gaining popularity, as an alternative, much less-invasive tissue source. Recent studies have shown, that the choice of one of these tissues can have profound effects not only on the culture yield, but also on the results of the experiments performed on these cultures.

First of all, the replicative lifespan of PSE cells isolated from the proximal and distal airway might not be equal. It has been observed, that CRC HAE bronchial cells cocultured with feeder cells could divide for at least 15 passages $[50,69]$. When HNEs were grown in the same $\mathrm{CRC}$ regimen, they showed a drop in cell growth already at P2 [27]. It has been speculated that the reduced BCs number, capable of proliferating, present in the sample, was responsible for this difference [27].

The difference between proximal and airway cells is also visible on the gene expression level. Despite an overlap in the gene expression profile between native HTEC and HBEC primary cells, the HAE from different airway regions have distinct molecular signatures [84]. Different gene expression profiles were also observed between HNE and human tracheobronchial cells [58].

There are contradicting reports regarding the differences in cellular physiology of the PSE cells from proximal and distal airway. Some studies have observed reduced IL-6 secretion and increased inflammatory response after cigarette smoke stimulation in HNEs, compared to HBEs[8]. Other studies have not observed such differences [85].

In any case, these observations mean that, when planning an experiment using primary airway epithelial cells, care should be taken when choosing the tissue source and the culturing platform. Moreover, to obtain reliable results, a careful validation of the tissue composition and physiology of the differentiated tissue is necessary.

\section{Conclusions}

The recent development of CRC HAE culturing method, which increased the proliferative efficiency of the primary HAE epithelial cultures, has allowed to obtain high numbers of HAE cells, which can be genetically modified, cryopreserved and can even be used for tissue engineering. However, despite the progress made in increasing the HAE cell proliferative lifespan and the ability to differentiate, the CRC HAE model is still not perfect. Further improvements should be made to increase its robustness and replicability. This includes a thorough comparison of the existing CRC culturing types (CRC HAE mono- and co-culture regimens), in order to assess their similarity to the native HAE epithelium in terms of physiology, which will determine their suitability for particular types of experiments. Improved knowledge on the factors influencing the differentiation and functioning of HAE, including the cross-talk between ECM and different tissue types, such as fibroblasts, will contribute to that progress. Identification of the factors influencing donorto-donor culture variability will help to predict the culture success, leading to a further increase in CRC culture replicability.

Of course, CRC cultures can in some aspects be replaced by other existing HAE culturing methods, such as $3 \mathrm{D}$ organoid cultures or iPSC-derived HAE cells. In all cases, the limitations of these different HAE culture types 
should always be carefully considered, before choosing the most appropriate HAE cellular model for particular study in airway research.

Considering the existing drawbacks of the iPSCs and organoid culture (reduced preservation of epigenetic marks in iPSCs culture or the technical difficulties related to organoid size control), there is a large chance that primary CRC HAE cultures, including mono- and co-cultured HAE cells, will still stay around for some time in respiratory research.

\begin{abstract}
Abbreviations
3T3: Albino Swiss mouse embryo fibroblasts feeder cell line; AECBM: Airway epithelial cell basal medium; ALI: Air-liquid interface; BAL: Bronchioalveolar lavage; BC: Basal cell; BEGM: Bronchial epithelial growth medium; BMPi: Inhibitor of the bone morphogenetic protein pathway; CF: Cystic fibrosis; CFTR: Cystic fibrosis transmembrane conductance regulator; COPD: Chronic obstructive pulmonary disease; CRC: Conditionally reprogrammed cell; CRISPR/ Cas9: Clustered regularly interspaced short palindromic repeats-cas9 system; DLL-1: Delta-like protein 1; DMH-1: Dorsomorphin homolog 1, inhibitor of activin receptor-like kinase 2; ECM: Extracellular matrix; GTPase: Guanosine triphosphate (GTP) hydrolase; HAE: Human airway epithelial; HBE: Human bronchial epithelium; HNE: Human nasal epithelium; HTE: Human tracheal epithelium; hTERT: Telomerase reverse transcriptase, catalytic subunit of telomerase; iPSCs: Induced pluripotent stem cells; KSFM: Keratinocyte serum-free medium; LHC-9: Lechner's serum-free bronchial epithelial growth medium; MCC: Multi-ciliated columnar cell; MMP: Metaloproteinase; mTOR: Mammalian target of rapamycin kinase of the phosphatidylinositol 3-kinase-related family; NEB: Neuroendocrine body; Notch ICD: Notch intracellular domain; PAK1: P21 associated kinase; PCD: Primary ciliary dyskinesia; PSE: Pseudostratified respiratory epithelium; ROCK: Rho-associated coiled-coil-containing protein kinase; ROCKi: Inhibitor of the Rho-associated coiled-coil-containing protein kinases; SAGM: Small airway growth medium; SMAD: Human homologs of the Caenorhabditis elegans SMA ("small" worm phenotype) and Drosophila MAD ("Mothers Against Decapentaplegic") family of genes; TEER: Transepithelial resistance.
\end{abstract}

\section{Acknowledgements}

Critical reading of the manuscript by Ewa Ziętkiewicz and Monika DrobnaŚledzińska (Institute of Human Genetics PAS), is gratefully acknowledged. Figures 1, 2 and 3 and the graphical abstract have been created with BioRender. com (http://biorender.com).

\section{Authors' contributions}

ZBB has designed the work, collected the data and performed all data analyses and interpretation, she had also drafted the manuscript and revised it. All authors have read and approved the final manuscript.

\section{Funding}

The project was financed from the funds of the National Science Centre (Poland) granted by decision number DEC-2013/09/D/NZ4/01692 (ZBB). ZBB was also supported by the Institute of Human Genetics, Polish Academy of Sciences through the internal grant for the implementation of a single scientific activity. Funding bodies had no influence on the study design, data collection, analysis, and interpretation or in writing the manuscript.

\section{Availability of data and materials}

Not applicable.

\section{Declarations}

Ethics approval

Not applicable.

\section{Consent to participate}

Not applicable.

\section{Consent for publication}

Not applicable.

\section{Competing interests}

The authors declare that they have no competing interests.

Received: 2 February 2021 Accepted: 16 April 2021

Published online: 27 May 2021

\section{References}

1. Hubbard R. The burden of lung disease. Thorax. 2006;61:557-8. https:// doi.org/10.1136/thx.2006.066050.

2. GBD. Causes of Death Collaborators (2017) Global, regional, and national age-sex specific mortality for 264 causes of death, 1980-2016: a systematic analysis for the global burden of disease study 2016. Lancet Lond Engl. 2016;390:1151-210. https://doi.org/10.1016/S0140-6736(17) 32152-9.

3. Mou H, Brazauskas K, Rajagopal J. Personalized medicine for cystic fibrosis: establishing human model systems. Pediatr Pulmonol. 2015;50(Suppl 40):S14-23. https://doi.org/10.1002/ppul.23233.

4. Basil MC, Katzen J, Engler AE, et al. The cellular and physiological basis for lung repair and regeneration: past, present, and future. Cell Stem Cell. 2020;26:482-502. https://doi.org/10.1016/j.stem.2020.03.009.

5. Mianné J, Ahmed E, Bourguignon C, et al. Induced pluripotent stem cells for primary ciliary dyskinesia modeling and personalized medicine. Am J Respir Cell Mol Biol. 2018;59:672-83. https://doi.org/10.1165/rcmb. 2018-0213TR.

6. Ibañez-Tallon I, Gorokhova S, Heintz N. Loss of function of axonemal dynein Mdnah5 causes primary ciliary dyskinesia and hydrocephalus. Hum Mol Genet. 2002;11:715-21. https://doi.org/10.1093/hmg/11.6.715.

7. Calvert BA, Ryan Firth AL. Application of iPSC to modelling of respiratory diseases. Adv Exp Med Biol. 2020;1237:1-16. https://doi.org/10.1007/ 5584_2019_430.

8. Comer DM, Elborn JS, Ennis M. Comparison of nasal and bronchial epithelial cells obtained from patients with COPD. PLOS ONE. 2012;7:e32924. https://doi.org/10.1371/journal.pone.0032924.

9. Staudt MR, Buro-Auriemma LJ, Walters MS, et al. Airway basal stem/progenitor cells have diminished capacity to regenerate airway epithelium in chronic obstructive pulmonary disease. Am J Respir Crit Care Med. 2014;190:955-8. https://doi.org/10.1164/rccm.201406-1167LE.

10. Barbato A, Frischer T, Kuehni CE, et al. Primary ciliary dyskinesia: a consensus statement on diagnostic and treatment approaches in children. Eur Respir J Off J Eur Soc Clin Respir Physiol. 2009;34:1264-76. https://doi.org/ 10.1183/09031936.00176608.

11. Berg A, Hallowell S, Tibbetts M, et al. High-throughput surface liquid absorption and secretion assays to identify F508del CFTR correctors using patient primary airway epithelial cultures. SLAS Discov Adv Life Sci R D. 2019;24:724-37. https://doi.org/10.1177/2472555219849375.

12. Maule G, Casini A, Montagna C, et al. Allele specific repair of splicing mutations in cystic fibrosis through AsCas 12a genome editing. Nat Commun. 2019. https://doi.org/10.1038/s41467-019-11454-9.

13. Broadbent L, Manzoor S, Zarcone MC, et al. Comparative primary paediatric nasal epithelial cell culture differentiation and RSV-induced cytopathogenesis following culture in two commercial media. PLOS ONE. 2020;15:e0228229. https://doi.org/10.1371/journal.pone.0228229.

14. Sims AC, Burkett SE, Yount B, Pickles RJ. SARS-CoV replication and pathogenesis in an in vitro model of the human conducting airway epithelium. Virus Res. 2008;133:33-44. https://doi.org/10.1016/j.virusres.2007.03.013.

15. Berical A, Lee RE, Randell SH, Hawkins F. Challenges facing airway epithelial cell-based therapy for cystic fibrosis. Front Pharmacol. 2019;10:74. https://doi.org/10.3389/fphar.2019.00074.

16. Morrisey EE, Hogan BLM. Preparing for the first breath: genetic and cellular mechanisms in lung development. Dev Cell. 2010;18:8-23. https:// doi.org/10.1016/j.devcel.2009.12.010. 
17. Rock JR, Randell SH, Hogan BLM. Airway basal stem cells: a perspective on their roles in epithelial homeostasis and remodeling. Dis Model Mech. 2010;3:545-56. https://doi.org/10.1242/dmm.006031.

18. Wang S, Wu J, Liu G-H. First stem cell transplantation to regenerate human lung. Protein Cell. 2018;9:244-5. https://doi.org/10.1007/ s13238-017-0498-z.

19. Lane C, Burgess S, Kicic A, et al. The use of non-bronchoscopic brushings to study the paediatric airway. Respir Res. 2005;6:53. https://doi.org/10. 1186/1465-9921-6-53.

20. Gu X, Karp PH, Brody SL, et al. Chemosensory functions for pulmonary neuroendocrine cells. Am J Respir Cell Mol Biol. 2014;50:637-46. https:// doi.org/10.1165/rcmb.2013-01990C.

21. Ruiz García S, Deprez M, Lebrigand K, et al. Novel dynamics of human mucociliary differentiation revealed by single-cell RNA sequencing of nasal epithelial cultures. Dev Camb Engl. 2019. https://doi.org/10.1242/ dev.177428.

22. Davis JD, Wypych TP. Cellular and functional heterogeneity of the airway epithelium. Mucosal Immunol. 2021. https://doi.org/10.1038/ s41385-020-00370-7.

23. Plasschaert LW, Žilionis $R$, Choo-Wing R, et al. A single-cell atlas of the airway epithelium reveals the CFTR-rich pulmonary ionocyte. Nature. 2018:560:377-81. https://doi.org/10.1038/s41586-018-0394-6.

24. Goldfarbmuren KC, Jackson ND, Sajuthi SP, et al. Dissecting the cellular specificity of smoking effects and reconstructing lineages in the human airway epithelium. Nat Commun. 2020. https://doi.org/10.1038/ s41467-020-16239-Z.

25. Zaragosi LE, Deprez M, Barbry P. Using single-cell RNA sequencing to unravel cell lineage relationships in the respiratory tract. Biochem Soc Trans. 2020;48:327-36. https://doi.org/10.1042/BST20191010.

26. Montoro DT, Haber AL, Biton $\mathrm{M}$, et al. A revised airway epithelial hierarchy includes CFTR-expressing ionocytes. Nature. 2018;560:319-24. https:// doi.org/10.1038/s41586-018-0393-7.

27. Reynolds SD, Rios C, Wesolowska-Andersen A, et al. Airway progenitor clone formation is enhanced by Y-27632-dependent changes in the transcriptome. Am J Respir Cell Mol Biol. 2016;55:323-36. https://doi.org/ 10.1165/rcmb.2015-0274MA.

28. Suprynowicz FA, Upadhyay G, Krawczyk E, et al. Conditionally reprogrammed cells represent a stem-like state of adult epithelial cells. Proc Natl Acad Sci. 2012;109:20035-40. https://doi.org/10.1073/pnas.12132 41109.

29. Boon M, Wallmeier J, Ma L, et al. MCIDAS mutations result in a mucociliary clearance disorder with reduced generation of multiple motile cilia. Nat Commun. 2014;5:4418. https://doi.org/10.1038/ncomms5418.

30. Randell SH, Fulcher ML, O’Neal W, Olsen JC. Primary epithelial cell models for cystic fibrosis research. Methods Mol Biol Clifton NJ. 2011;742:285310. https://doi.org/10.1007/978-1-61779-120-8_18.

31. Whitcutt MJ, Adler KB, Wu R. A biphasic chamber system for maintaining polarity of differentiation of cultured respiratory tract epithelial cells. Vitro Cell Dev Biol. 1988;24:420-8. https://doi.org/10.1007/BF02628493.

32. Randell SH, Walstad L, Schwab UE, et al. Isolation and culture of airway epithelial cells from chronically infected human lungs. Vitro Cell Dev Bio Anim. 2001;37:480-9. https://doi.org/10.1290/1071-2690(2001)037<0480: IACOAE $>2.0 . C O ; 2$

33. Fulcher ML, Gabriel S, Burns KA, et al. Well-differentiated human airway epithelial cell cultures. Methods Mol Med. 2005;107:183-206. https://doi. org/10.1385/1-59259-861-7:183.

34. Jorissen M, Bessems A. Normal ciliary beat frequency after ciliogenesis in nasal epithelial cells cultured sequentially as monolayer and in suspension. Acta Otolaryngol (Stockh). 1995;115:66-70. https://doi.org/10.3109/ 00016489509133349

35. Bukowy Z, Ziętkiewicz E, Witt M. In vitro culturing of ciliary respiratory cells-a model for studies of genetic diseases. J Appl Genet. 2011;52:39_ 51. https://doi.org/10.1007/s13353-010-0005-1.

36. Gilpin SE, Wagner DE. Acellular human lung scaffolds to model lung disease and tissue regeneration. Eur Respir Rev. 2018. https://doi.org/10. 1183/16000617.0021-2018.

37. Jorissen M, Willems T. The secondary nature of ciliary (dis)orientation in secondary and primary ciliary dyskinesia. Acta Otolaryngol (Stockh). 2004;124:527-31. https://doi.org/10.1080/00016480410016270.

38. Neugebauer P, Endepols H, Mickenhagen A, Walger M. Ciliogenesis in submersion and suspension cultures of human nasal epithelial cells.
Eur Arch Otorhinolaryngol. 2003;260:325-30. https://doi.org/10.1007/ s00405-002-0562-y.

39. Lechner JF, LaVeck MA. A serum-free method for culturing normal human bronchial epithelial cells at clonal density. J Tissue Cult Methods. 1985;9:43-8. https://doi.org/10.1007/BF01797773.

40. Song J, Heijink IH, Kistemaker LEM, et al. Aberrant DNA methylation and expression of SPDEF and FOXA2 in airway epithelium of patients with COPD. Clin Epigenetics. 2017;9:42. https://doi.org/10.1186/ s13148-017-0341-7.

41. Gras D, Bourdin A, Vachier I, et al. An ex vivo model of severe asthma using reconstituted human bronchial epithelium. J Allergy Clin Immunol. 2012;129:1259-1266.e1. https://doi.org/10.1016/j.jaci.2012.01.073.

42. Hiemstra PS, Grootaers G, van der Does AM, et al. Human lung epithelial cell cultures for analysis of inhaled toxicants: lessons learned and future directions. Toxicol In Vitro. 2018;47:137-46. https://doi.org/10.1016/j.tiv. 2017.11.005.

43. Gomes KMS, Costa IC, dos Santos JF, et al. Induced pluripotent stem cells reprogramming: epigenetics and applications in the regenerative medicine. Rev Assoc Médica Bras. 2017;63:180-9. https://doi.org/10.1590/ 1806-9282.63.02.180.

44. Hynds RE, Bonfanti P, Janes SM. Regenerating human epithelia with cultured stem cells: feeder cells, organoids and beyond. EMBO Mol Med. 2018;10:139-50. https://doi.org/10.15252/emmm.201708213.

45. Awatade NT, Wong SL, Hewson CK, et al. Human primary epithelial cell models: promising tools in the era of cystic fibrosis personalized medicine. Front Pharmacol. 2018. https://doi.org/10.3389/fphar.2018.01429.

46. Xia S, Liu J, Yang Y, et al. Coupled CRC 2D and ALI 3D cultures express receptors of emerging viruses and are more suitable for the study of viral infections compared to conventional cell lines. Stem Cells Int. 2020 https://doi.org/10.1155/2020/2421689.

47. Zabner J, Karp P, Seiler M, et al. Development of cystic fibrosis and noncystic fibrosis airway cell lines. Am J Physiol Lung Cell Mol Physiol. 2003;284:L844-854. https://doi.org/10.1152/ajplung.00355.2002.

48. Sheikh Z, Bradbury P, Pozzoli M, et al. An in vitro model for assessing drug transport in cystic fibrosis treatment: characterisation of the CuFi-1 cell line. Eur J Pharm Biopharm. 2020;156:121-30. https://doi.org/10.1016/j. ejpb.2020.09.002.

49. Kicic A, Sutanto EN, Stevens PT, et al. Intrinsic Biochemical and Functional Differences in Bronchial Epithelial Cells of Children with Asthma. Am J Respir Crit Care Med. 2006;174:1110-8. https://doi.org/10.1164/rccm. 200603-3920C

50. Martinovich KM, losifidis T, Buckley AG, et al. Conditionally reprogrammed primary airway epithelial cells maintain morphology, lineage and disease specific functional characteristics. Sci Rep. 2017;7:17971. https://doi.org/ 10.1038/s41598-017-17952-4.

51. Gray TE, Guzman K, Davis CW, et al. Mucociliary differentiation of serially passaged normal human tracheobronchial epithelial cells. Am J Respir Cell Mol Biol. 1996;14:104-12. https://doi.org/10.1165/ajrcmb.14.1.85344 81.

52. Stewart CE, Torr EE, Mohd Jamili NH, et al. Evaluation of differentiated human bronchial epithelial cell culture systems for asthma research. $J$ Allergy. 2012;2012:e943982. https://doi.org/10.1155/2012/943982.

53. Mao H, Wang Y, Yuan W, Wong LB. Ciliogenesis in cryopreserved mammalian tracheal epithelial cells cultured at the air-liquid interface. Cryobiology. 2009;59:250-7. https://doi.org/10.1016/j.cryobiol.2009.07.012.

54. You Y, Brody SL. Culture and differentiation of mouse tracheal epithelial cells. Methods Mol Biol Clifton NJ. 2013;945:123-43. https://doi.org/10. 1007/978-1-62703-125-7_9.

55. Hild M, Jaffe AB. Production of 3-D airway organoids from primary human airway basal cells and their use in high-throughput screening. Curr Protoc Stem Cell Biol. 2016;37:IE.9.1-IE.9.15. https://doi.org/10.1002/cpsc.1.

56. Dye BR, Hill DR, Ferguson MA, et al. In vitro generation of human pluripotent stem cell derived lung organoids. Elife. 2015;4:e05098. https://doi. org/10.7554/eLife.05098.

57. Brewington JJ, Filbrandt ET, LaRosa FJ, et al. Generation of human nasal epithelial cell spheroids for individualized cystic fibrosis transmembrane conductance regulator study. J Vis Exp JoVE. 2018. https://doi.org/10. $3791 / 57492$

58. Kumar PA, Hu Y, Yamamoto Y, et al. Distal airway stem cells yield alveoli in vitro and during lung regeneration following $\mathrm{H} 1 \mathrm{~N} 1$ influenza infection. Cell. 2011;147:525-38. https://doi.org/10.1016/j.cell.2011.10.001. 
59. Sachs N, Papaspyropoulos A, Zomer-van Ommen DD, et al. Long-term expanding human airway organoids for disease modeling. EMBO J. 2019. https://doi.org/10.15252/embj.2018100300.

60. Nikolić MZ, Rawlins EL. Lung organoids and their use to study cell-cell interaction. Curr Pathobiol Rep. 2017;5:223-31. https://doi.org/10.1007/ s40139-017-0137-7.

61. Horani A, Nath A, Wasserman MG, et al. Rho-associated protein kinase inhibition enhances airway epithelial basal-cell proliferation and lentivirus transduction. Am J Respir Cell Mol Biol. 2013;49:341-7. https://doi.org/10. 1165/rcmb.2013-0046TE.

62. Watanabe K, Ueno M, Kamiya D, et al. A ROCK inhibitor permits survival of dissociated human embryonic stem cells. Nat Biotechnol. 2007;25:681-6. https://doi.org/10.1038/nbt1310.

63. Chapman S, Liu X, Meyers C, et al. Human keratinocytes are efficiently immortalized by a Rho kinase inhibitor. J Clin Invest. 2010;120:2619-26. https://doi.org/10.1172/JCl42297.

64. Liu X, Ory V, Chapman S, et al. ROCK inhibitor and feeder cells induce the conditional reprogramming of epithelial cells. Am J Pathol. 2012;180:599_ 607. https://doi.org/10.1016/j.ajpath.2011.10.036.

65. Wolf S, Perez GF, Mukharesh L, et al. Conditional reprogramming of pediatric airway epithelial cells: A new human model to investigate early-life respiratory disorders. Pediatr Allergy Immunol Off Publ Eur Soc Pediatr Allergy Immunol. 2017. https://doi.org/10.1111/pai.12810.

66. Butler CR, Hynds RE, Gowers KHC, et al. Rapid expansion of human epithelial stem cells suitable for airway tissue engineering. Am J Respir Crit Care Med. 2016;194:156-68. https://doi.org/10.1164/rccm. 201507-14140C

67. Koh KD, Siddiqui S, Cheng D, et al. Efficient RNP-directed human gene targeting reveals SPDEF is required for IL-13-induced Mucostasis. Am J Respir Cell Mol Biol. 2020;62:373-81. https://doi.org/10.1165/rcmb. 2019-026600

68. Jonsdottir HR, Marti S, Geerts D, et al. Establishment of primary transgenic human airway epithelial cell cultures to study respiratory virus-host interactions. Viruses. 2019. https://doi.org/10.3390/v11080747.

69. Peters-Hall JR, Coquelin ML, Torres MJ, et al. Long-term culture and cloning of primary human bronchial basal cells that maintain multipotent differentiation capacity and CFTR channel function. Am J Physiol Lung Cel Mol Physiol. 2018;315:L313-27. https://doi.org/10.1152/ajplung.00355. 2017

70. Gentzsch M, Boyles SE, Cheluvaraju C, et al. Pharmacological rescue of conditionally reprogrammed cystic fibrosis bronchial epithelial cells. Am J Respir Cell Mol Biol. 2017;56:568-74. https://doi.org/10.1165/rcmb. 2016-0276MA.

71. Mou H, Vinarsky V, Tata PR, et al. Dual SMAD signaling inhibition enables long-term expansion of diverse epithelial basal cells. Cell Stem Cell. 2016;19:217-31. https://doi.org/10.1016/j.stem.2016.05.012.

72. Zhang C, Lee HJ, Shrivastava A, et al. Long-term in vitro expansion of epithelial stem cells enabled by pharmacological inhibition of PAK1-ROCKmyosin II and TGF- $\beta$ signaling. Cell Rep. 2018;25:598-610.e5. https://doi. org/10.1016/j.celrep.2018.09.072.

73. Haller S, Kapuria S, Riley RR, et al. mTORC1 activation during repeated regeneration impairs somatic stem cell maintenance. Cell Stem Cell. 2017:21:806-818.e5. https://doi.org/10.1016/j.stem.2017.11.008.
74. Lu J, Zhu X, Shui JE, et al. Rho/SMAD/mTOR triple inhibition enables long-term expansion of human neonatal tracheal aspirate-derived airway basal cell-like cells. Pediatr Res. 2020. https://doi.org/10.1038/ s41390-020-0925-3.

75. Gerovac BJ, Valencia M, Baumlin N, et al. Submersion and hypoxia inhibit ciliated cell differentiation in a notch-dependent manner. Am J Respir Cell Mol Biol. 2014;51:516-25. https://doi.org/10.1165/rcmb. 2013-02370C.

76. Hynds RE, Butler CR, Janes SM, Giangreco A. Expansion of human airway basal stem cells and their differentiation as 3D tracheospheres. Methods Mol Biol Clifton NJ. 2019;1576:43-53. https://doi.org/10.1007/7651_ 2016_5.

77. Awatade NT, Wong SL, Pandzic E, et al (2020) Significant functional differences despite morphological and molecular similarity in fully differentiated matched Conditionally Reprogrammed (CRC) and Feeder free dual SMAD inhibited expanded human nasal epithelial cells. bioRxiv. https:// doi.org/10.1101/2020.05.29.120006

78. Schogler A, Blank F, Brugger M, et al. Characterization of pediatric cystic fibrosis airway epithelial cell cultures at the air-liquid interface obtained by non-invasive nasal cytology brush sampling. Respir Res. 2017;18:215. https://doi.org/10.1186/s12931-017-0706-7.

79. Kmit A, Marson FAL, Pereira SV-N, et al. Extent of rescue of F508del-CFTR function by VX-809 and VX-770 in human nasal epithelial cells correlates with SNP rs7512462 in SLC26A9 gene in F508del/F508del Cystic Fibrosis patients. Biochim Biophys Acta BBA - Mol Basis Dis. 2019;1865:1323-31. https://doi.org/10.1016/j.bbadis.2019.01.029.

80. Gras D, Petit A, Charriot J, et al. Epithelial ciliated beating cells essential for ex vivo ALI culture growth. BMC Pulm Med. 2017;17:80. https://doi.org/ 10.1186/s12890-017-0423-5.

81. Manawadu BR, Mostow SR, LaForce FM. Local anesthetics and tracheal ring ciliary activity. Anesth Analg. 1978:57:448-52. https://doi.org/10. 1213/00000539-197807000-00014.

82. Tontschev G, Dexheimer A. Effect of local anesthetics on ciliary activity of the human tracheobronchial mucosa (studies in vitro). Z Erkr Atmungsorgane. 1986;166:175-9.

83. Boon $M$, Jorissen $M$, Jaspers $M$, et al. The influence of nebulized drugs on nasal ciliary activity. J Aerosol Med Pulm Drug Deliv. 2016;29:378-85. https://doi.org/10.1089/jamp.2015.1229.

84. Gillen AE, Yang R, Cotton CU, et al. Molecular characterization of gene regulatory networks in primary human tracheal and bronchial epithelia cells. J Cyst Fibros Off J Eur Cyst Fibros Soc. 2018;17:444-53. https://doi. org/10.1016/j.jcf.2018.01.009.

85. Mihaylova VT, Kong Y, Fedorova O, et al. Regional differences in airway epithelial cells reveal tradeoff between defense against oxidative stress and defense against rhinovirus. Cell Rep. 2018;24:3000-3007.e3. https:// doi.org/10.1016/j.celrep.2018.08.033.

\section{Publisher's Note}

Springer Nature remains neutral with regard to jurisdictional claims in published maps and institutional affiliations.

Ready to submit your research? Choose BMC and benefit from

- fast, convenient online submission

- thorough peer review by experienced researchers in your field

- rapid publication on acceptance

- support for research data, including large and complex data types

- gold Open Access which fosters wider collaboration and increased citations

- maximum visibility for your research: over $100 \mathrm{M}$ website views per year

At BMC, research is always in progress.

Learn more biomedcentral.com/submissions 